\title{
Jaunosios kartos patriotizmas Ukrainoje hibridinio karo laikotarpiu
}

Po Euromaidano (2013 m.) ir karo Rytų Ukrainoje (2014 m.) šios šalies jaunimas atsidūrẻ naujoje situacijoje - turi gyventi hibridinio karo laikotarpiu. Straipsnyje analizuojama jaunosios kartos situacija Ukrainoje, gyvenant šio naujo karo sąlygomis. Autorius taip pat bando atsakyti ị klausimą, ar jaunuoliai jaučiasi patriotais, vertindamas jų norą ginti gimtinę, vykstant hibridiniam karui. Rezultatai rodo pirmąją jaunuolių patirtį, atsidūrus neịprastoje situacijoje. Atsidūrę naujoje realybẻje, jie turi gerai suvokti patriotizmą. Patriotizmo pagrindą sudaro pagrindiniai motyvai, susiję su pareigos savo šaliai jausmu ir vienybės siekiu kartais visiškai skirtingose šalies dalyse. Straipsnis atskleidè, kad jaunosios kartos patriotizmas ne tik vis dar egzistuoja, bet ir sudaro pagrindą, formuosiantị būsimas kartas.

\section{lvadas}

Ukraina - viena pirmujų didžiųjų naujo tipo hibridinio karo aukų. Dèl to valstybe prarado didelę savo teritorijos dali (Krymą ir Donbasą). Be to, ši situacija paveikè jaunuolius, kuriems dabar sunkiau pradèti savo, kaip suaugusių žmonių, gyvenimą. Atliktame tyrime dalyvavo reprezentatyvi studentų grupé (užpildytos 1043 apklausos anketos) iš visų šalies regionų (išskyrus okupuotą teritoriją). Dauguma apklausoje dalyvavusių studentų yra 17, 18 ir 19 metų. Šie studentai buvo maždaug 14-16 metų tuo metu, kai prasidèjo ginkluotas konfliktas Rytuose ir buvo aneksuotas Krymo pusiasalis. Taigi, respondentai užaugo nuolatinių konfliktų ir ginkluotų kovų (su vadinamųjų Donecko Liaudies Respublikos ir Luhansko Liaudies Respublikos kovotojais) situacijoje bei veikiami tiek išorinès, tiek vidaus propagandos (skirtos piliečių patriotinių jausmų kurstymui). Jų tėvai, broliai ir seserys ar vyresni draugai galëjo kovoti

\footnotetext{
* Dr. Mateusz Kamionka - Krokuvos Edukacinès komisijos pedagoginio universiteto Politikos ir administracinių mokslų instituto asistentas. Adresas korespondencijai: ul. Podchorążych 2, 30-084 Kraków, Poland, tel. +48 1266264 46; el. p. mateusz.kamionka@up.krakow.pl ** Šiame straipsnyje autorius naudojo duomenis, kurie buvo gauti vykdant Lenkijos nacionalinio mokslo centro finansuojamą projektą (sutartis Nr. 2016/23/D/HS5/00902). Straipsnio autorius buvo projekto vadovas.
} 
fronte (būti sužaloti arba žuvo), taip pat tarnauti kaip savanoriai ${ }^{1}$. Kartu derètų pabrèžti, kad Ukrainos gyventojų gyvenimo lygis labai smuko, o tai taip pat turëjo ittakos jaunuolių gyvenimui. Per penkerius konflikto metus Donecko ir Luhansko ekonomika susitrauke perpus. Visa šalis prarado daugiau nei 15 procentų BVP². Straipsnyje siekiama parodyti ypatingą jaunuolių patriotizmo specifiką, susiformavusią hibridinio konflikto laikotarpiu, kuri gali radikaliai skirtis nuo situacijos, pvz., kaimyninejje Lenkijoje, kur tokia problema neegzistuoja. Be to, straipsnyje paaiškinama teorinè patriotizmo ir hibridinio karo koncepcijos dalis, kad skaitytojas susidarytų detalų dabartinès Ukrainos problemos vaizdą.

\section{Patriotizmas ir hibridinis karas. Literatūros apžvalga}

Daugelyje šalių, kurių tautos istoriškai susiformavusios, patriotizmas yra esminis požiūris, iš esmès veikiantis nacionalinių bendruomenių funkcionavimą. Kembridžo žodyne „patriotizmas“ apibrèžiamas kaip „meilès savo šaliai jausmas, kuris yra stipresnis už meilę kitoms [šalims], ir didžiavimasis ja“, o „patriotas“ - kaip „asmuo, kuris myli šalị ir kovos už ją, jei to prireiktų“3. Šiais laikais ị ši apibrežimą žvelgiama kur kas platesniame kontekste ${ }^{4}$. Lenkų žodynų autorius Vladislavas Kopalinskis pateikia platesni apibrèžimą. Mokslininkas apibūdina patriotizmą kaip „meilę tèvynei, savo tautai, kartu su noru aukotis dèl jos, pripažistant kitų tautų teises ir jas gerbiant “" Kitame patriotizmo apibrèžime teigiama, kad patriotizmas yra „socialinis - politinis požiūris ir elgesys, išreiškiantis prisirišimą prie savo bendruomenès, atsidavimą jai, kartu gerbiant kitas bendruomenes. Tai taip pat yra specifinè solidarumo su bendruomene forma, iggyvendinama laikantis jos nustatytų teisinių principų ir normų, įskaitant vadinamuosius pilietinius ịsipareigojimus" ${ }^{\text {"6 }}$. Nuodugniai išanalizavus literatūrą, sunku nesusidaryti ịspūdžio, kad yra dvi patriotizmo suvokimo perspektyvos. Patriotizmas gali būti subjektyvus, kai apibrèžiamas kaip požiūrio ị tèvynę visuma. Šiuo atveju svarbiausi yra kolektyviniai asmens tikslai ir jie yra svarbesni nei

\footnotetext{
${ }^{1}$ Konflikto pradžioje savanorystė Ukrainos kariuomenèje buvo labai paplitęs reiškinys.

${ }^{2}$ Trusiewicz I. (2019, June 1), „How much does Ukraine`s economy lose in the war?", Rzeczpospolita, https://www.rp.pl/Gospodarka/306019988-Ile-na-wojnie-traci-gospodarka-Ukrainy.html, accessed 11. 10. 2020.

${ }^{3}$ Patriotism (n.d.), In Cambridge dictionary, www. dictionary.cambridge.org/dictionary/english/, accessed 11. 10. 2020.

${ }^{4}$ Chmielewski J. (2006), „A modern variety of patriotism”, Edukacja i Dialog, no. 4 (177/2006).

${ }^{5}$ Kopaliński W. (2007), Dictionary of foreign words and phrases with almanac II. Warsaw, Poland: Rytm Oficyna Wydawnicza, p. 62.

${ }^{6}$ Chodubski A. (2002), „An individual, a nation, a state“ in B. Szmulik, M. Żmigrodzki (Ed.), Introduction to the science of the state and politics, Lublin, Poland:UMCS, p. 159.
} 
asmens (pvz., piliečio) poreikiai. Jis yra susijęs su emocijomis ir dažnai su regionu ar šalimi, iš kurios asmuo yra kilęs. Pagal šią koncepciją, asmuo yra labiau susijęs su kolektyvu nei su vietove, kur jie kartu gyvena, ar kalba, kuria jie kalba. Individams būdingos bendros jų tautos vertybès, pasiekimai, savybès ar nuopelnai. Jis apima bendrą istoriją, panašų ịspūdžių perteikimo ir patirčių išraiškos arba įvykių ir būdingų apeigų vertinimo būdą ${ }^{7}$.

Antroji teorija, kuri dažnai taikoma apibrèžimuose, yra pilietinių ịsipareigojimų vykdymo tvirtumas, t. y. gyvenimas kolektyve pagal nacionalinės bendruomenès sukurtus bendrus standartus ir principus. [̦sipareigojimų vykdymas ir gyvenimas pagal juos apibrèžiamas kaip bendros gerovès ir saugos užtikrinimo siekis ${ }^{8}$. Pasak lenkų pedagogès Jolantos Szczurkowskos, yra trys patriotinio požiūrio komponentai: kognityvinis, emocinis - vertinimo ir elgesio. Kognityvinis komponentas - tai asmens žinios, jo nuomonès apie tẻvynę šaltinis. Ši nuomonè susijusi su istorija, kultūra, gamtinemis sąlygomis arba ekonomine ir politine situacija. Antrasis patriotinio požiūrio komponentas, t. y. emocinis ir vertinimo, apima tautos ir tèvynès vertinimą ir to nulemtą emocinę reakciją j ̣̌iuos dalykus. Su patriotiniu požiūriu siejamos emocijos gali skirtis savo kryptimi, sudetingumu ar intensyvumu. Paskutinis komponentas susijęs su elgesiu, t. y. asmens pasirengimu imtis veiksmų dèl savo tèvynès. Patriotinis požiūris gali pasireikšti ịvairiai - nuo véliavos iškèlimo valstybinių švenčių dienomis iki tarnybos kariuomenejje?

Rašant apie Ukrainą, taip pat verta aptarti apibrěžimą, kuris svarbus, kalbat apie šalį, kurioje vyksta hibridinis karas. Dèl to nesunku rasti apžvalgų, kuriose teigiama, jog patriotizmas yra kažkas tarp kosmopolitizmo ir nacionalizmo - pilietis tuo pat metu gali būti ir nacionalistas, ir kosmopolitas ${ }^{10}$. Kosmopolitizmas dažnai supriešinamas su nacionalizmu, bet taip yra ne visada. Pavyzdžiui, patriotas gali manyti, kad nacionalisto tvirtai remiamas karas kenkia šaliai. Patriotizmas gali būti nacionalinio pasididžiavimo šaltinis, tačiau jis taip pat gali paskatinti padaryti kritiškas išvadas dèl tautos ar valstybès ir net sukelti gèdos jausmą dèl atitinkamos valstybès bendruomenès ${ }^{11}$.

\footnotetext{
${ }^{7}$ Stach Ł., Marzęcki R. (2014), „Fact or artifact? Patriotism in the life of young Poles“, Annales Universitatis Paedagogicae Cracoviensis. Studia Politologica, no. 13, p. 245-262.

${ }^{8}$ Moore M. (2009), „Is Patriotism an Associative Duty?“, Journal of Ethics 13 (4), p. 383-399, doi: 10.1007/ s10892-009-9064-0.

${ }^{9}$ Szczurkowska J. (2016), I am a patriot. Psychology of patriotism, Warsaw, Poland: Difin SA, p. 92-93.

${ }^{10}$ Bayram A. B. (2019), „Nacionalist cosmopolitanism: the psychology of cosmopolitanism, nacional identity, and going to war for the country", Nations and Nacionalism, 25, p. 757- 781, doi:/10.1111/ nana. 12476.

${ }^{11}$ Audi R. (2009), „Nacionalism, Patriotism, and Cosmopolitanism in an Age of Globalization“, The Journal of Ethics. 13, p. 365-381, doi: 10.1007/s10892-009-9068-9.
} 


\subsection{Hibridinis karas}

Terminas „hibridinė veikla“, kuri paskui pavadinta „hibridiniu karu“, pirmą kartą buvo pavartotas XXI a. pradžioje. $2002 \mathrm{~m}$. Viljamas J. Nemethas ji vartojo savo darbe „Ateities karas ir Čečènija: hibridinio karo atvejis“. Negalime kalbẻti apie hibridinị karą (konfliktą) kaip apie vienu terminu ịvardijamą veiklą. Ši koncepcija yra kolektyvinè ir apima įvairius veiksnius ir veiksmus skirtinguose „frontuose", tokiuose kaip kibernetinis karas, terorizmas, piratavimas, tarptautinis organizuotas nusikalstamumas ir masinio naikinimo ginklų platinimas, taip pat karas, siekiant palaužti civilių gyventojų moralę. Nikas Marano (Jūrų pèstininkų korpuso pratybų ir mokymo štabas, JAV) pristatė pagrindinį paradigmos pokyti, nurodydamas tradicinio karo ir nereguliariojo karo skirtumus. Pastarojo pagrindą sudaro netiesioginių ir netradicinių metodų ir priemonių naudojimas, siekiant demoralizuoti, žlugdyti ir išvarginti priešininką, užuot nugalëjus jị tiesioginès tradicinès karinès konfrontacijos metu. Antroje dalyje pristatomas kitoks nereguliariojo karo operacijų, siekiant žlugdyti priešininko galią, įtaką ir valią bei iggauti gyventojų paramą, dèmesio centras (žr. 1 pav.).

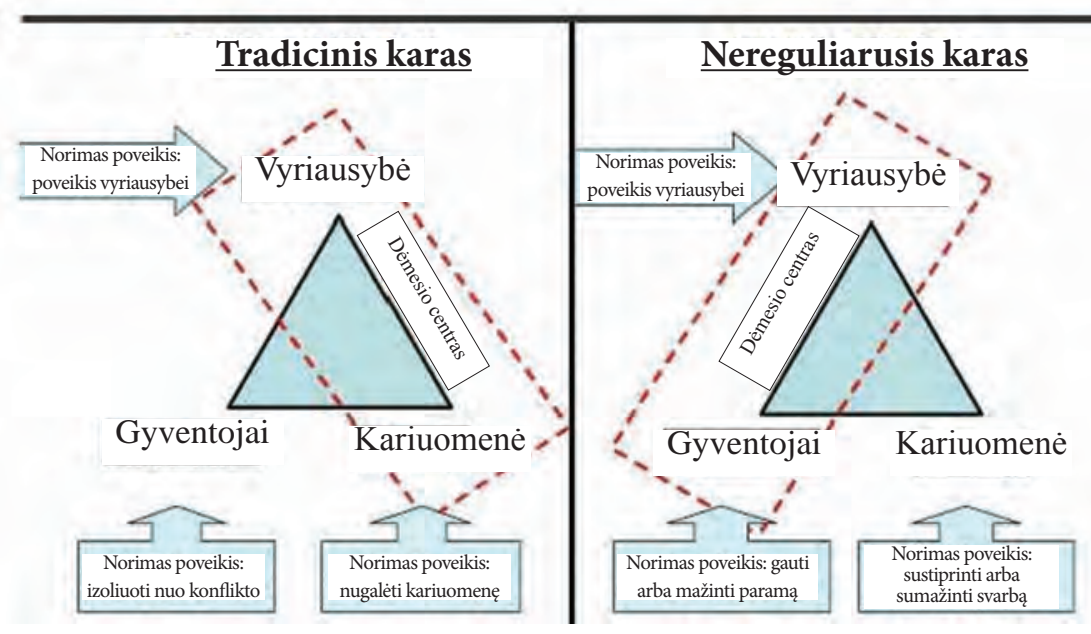

1 pav. Tradicinio ir nereguliariojo karo skirtumai

Šaltinis: Nikas Marano, Mažuju padalinių vadovų rengimas, vykstant ilgalaikiam karui, Jūrų pèstininku korpuso pratybu ir mokymo štabas ${ }^{12}$

\footnotetext{
${ }^{12}$ Anton M. (2016), „Hybrid Pedagogies For Hybrid War“, Scientific Research And Education In The Air Force, 18, p. 509-516, doi: 10.19062/2247-3173. 2016. 18. 23.
} 
Daugelis mokslininkų hibridinio karo koncepcijos šaltinių ieško Rusijos kariuomenès generalinio štabo viršininko generolo Valerijaus Gerasimovo parašytame straipsnyje. $2013 \mathrm{~m}$. vasario mèn. jis rašè: „[L]abai pasikeite paties karo taisyklès. Kai kuriais atvejais nekarinių metodų naudojimas, siekiant politinių ir strateginių tikslų, pasiteisino kaip kur kas veiksmingesnè priemonè nei jejgos naudojimas... Plačiai naudojamos asimetrinès priemonès gali padèti neutralizuoti priešo pranašumą. Jos apima specialiųjų operacijų pajègų naudojimą ir vidinị pasipriešinimą nuolatinio fronto sukūrimui priešo valstybẻje bei propagandos priemonių poveikị, nuolat gerinamas formas ir metodus. ${ }^{\text {13 }}$ Nesunku atspeti, kad straipsnyje nebuvo minimi konkretūs pavadinimai, tokie kaip „Ukraina“ ar „hibridinis karas“. Vis dèlto, kaip rašè Maria Snegovaja, šis straipsnis pavertė „Gerasimovą Rusijos „hibridinio karo“ metodo veidu“. Vakarų mokslininkai dažniausiai svarsto ir sutinka su šia nuomone ${ }^{14}$. Pasak Gerasimovo, plačiai suprantamas informacinis karas yra atskiro tipo konfrontacija, karo metu vykdoma taikant informacines technines ir informacines psichologines priemones praktiškai visose valstybès veiklos srityse (kaip politika, ekonomika, diplomatija, humanitarinè ir karinè veikla ${ }^{15}$. Latvių mokslininkas Jans Berzins pateikia hibridinio karo klausimus, pasitelkdamas Latvijos Respublikos traktuotę. Pasak jo, Rusijos Federacija pakeite tradicinị elgesị, siejamą su ginkluotais konfliktais, pereidama prie sudètingesnių ir visapusiškesnių operacijų. Jis pabrěžè, kad konflikto Ukrainoje metu Rusija pradejjo taikyti anksčiau patvirtintos psichologinio karo koncepcijos prielaidas, kurios turi itakos Rusijos invazijai palankiai ir nepalankiai aplinkai, bauginimui, korupcijai, visuomenès atstovų kyšininkavimui bei plataus masto propagandai ir dezinformacijos veiklai žiniasklaidoje, įskaitant internetą. Taip buvo siekiama susilpninti Rusijai nepalankių grupių pasipriešinimą ${ }^{16}$. Sunku nesutikti, kad ši didžiulè psichologinè ir propagandos kampanija neturejjo įtakos pilietinei visuomenei, įskaitant Ukrainoje gyvenantị jaunimą, ypač kai didžioji dalis tokios veiklos buvo vykdoma internete, kuriuo dažniausiai naudojasi jaunuoliai (taip pat vertètų pabrèžti, kad jaunuoliai, gyvenantys labiau rytiniuose Ukrainos regionuose, kur kas dažniau naudojasi „rusiška interneto dalimi“ nei jų bendraamžiai šalies vakaruose).

\footnotetext{
${ }^{13}$ Gerasimov V. (2013), „The Value of Science in Anticipation“, Military Industrial Courier, 8(476). Retrieved from http://www.vpk-news.ru/articles/14632, accessed 11. 10. 2020.

${ }^{14}$ Snegovaya M. (2015), „Putin's information warfare in Ukraine: Soviet origins of Russia’s hybrid warfare“. Washington, D. C., Institute for the Study of War, p. 10.

${ }^{15}$ Snegovaya M. (2015), Op. cit. p. 11-12; Galeotti M. (2016), Hybrid War or Gibridnaya Voina? Getting Russia's non-linear military challenge right, p. 44-47.

${ }^{16}$ Berzins, J. (2014), „Russia’s New Karta Warfare In Ukraine: Implications for Latvian Defense Policy“,

Nacional Defense Academy of Latvia, Center for Security and Strategic Research, Policy Paper, 2014, no. 2, 6.
} 


\subsection{Kodèl Ukraina?}

Sunku pasakyti, ar Vladimiras Putinas planavo užimti Krymą prieš Euromaidaną (jei taip, greičiau, sunaikinti visą Ukrainos valstybę) $)^{17}$. Vis dèlto Rusijos žiniasklaidoje, akademiniame ir politiniame diskurse visada figūravo „Krymo

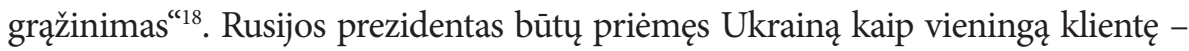
valstybę, kurios ekonomika ir gynyba priklausytų nuo Rusijos (su ekstrateritorine laivyno baze Juodojoje jūroje), ir kaip sieną su NATO šalimis prie Bosforo sąsiaurio, kuri galettų tęstis. Tačiau tai priklausẻ nuo to, ar Ukrainos vadovas išliktų visiškai pavaldus Maskvai. Kai toks pavaduotojas staiga susidūrẻ su grèsme būti pašalintam iš pareigų, Putinas suvoke trumpalaikę galimybę išspręsti Krymo klausimą ir kartu padidinti populiarumą savo šalyje ir ja pasinaudojo. Jis žinojo, kad Krymas yra natūrali karinè bazè. Šiuo metu ja naudojasi Rusijos Federacija, bet tai gali pasikeisti ị valdžią Ukrainoje atejjus opozicijai. Jau 2014 m. vasario 4 d., likus dviem savaitėms iki skuboto Janukovičiaus išvykimo iš Kijevo, Putino patikètiniai nusprendè, kad prorusišką režimą gelbèti Kijeve beprasmiška. Vis dèlto bendras chaosas sudarè galimybę manipuliuoti galiojančiomis teisès procedūromis, siekiant pasiruošti kelių Ukrainos teritorijų prijungimui prie Rusijos Federacijos, kas ir nutiko. Rusijos karinè agresija prieš Ukrainą yra ilgalaikis veiksnys, turintis įtakos Ukrainos politikos ir ekonomikos realijoms, kariuomenei ir visuomenei. Rusija Ukrainoje kariauja naujo tipo karą. Pagal formą tai - hibridinis karas, pagal struktūrą - asimetrinis. Naujo tipo karo pobūdis sudare galimybę aneksuoti Krymo Autonominę Respubliką, o tada remti radikalius vietos elementus ir visišką Rusijos karių invaziją i r rytinius Ukrainos regionus ${ }^{19}$. Ši neišspręsta tarptautinè konfliktinė situacija tęsiasi iki šios dienos, o jaunuoliai buvo priversti gyventi tokioje keblioje padètyje, kuri visiškai skyrèsi nuo kitų Europos šalių bendraamžių gyvenimo. Tokiu atveju derètų pasinaudoti ukrainiečių mokslininko Ihoro Ruszczenkos siūlymu hibridinį karą vadinti „naujųjų kartų karu“20. Taip pat verta paminèti, kad šiuo metu Ukrainoje vykstančių konfliktų, nepaisant žinomų veiksnių, negalima tiesiog vadinti Ukrainos ir Rusijos karu. Dèl to, pasak autoriaus, būtų geriau vartoti sąvoką „hibridinis karas“. Net Ukrainos prezidentas Vladimiras Zelenskis nevar-

\footnotetext{
${ }^{17}$ Coalson R. (2015, March 11), „News Analysis: The Plot to Seize Crimea“ Radio Free Europe Radio Liberty, http://www.rferl.org/content/ukraine-russia-putin-plot-seize-crimea/26894212.html, accessed 11. 10. 2020.

${ }^{18}$ The author of the article, during his studies in Moscow in 2010, often met with the theses of academic teachers or ordinary people on the need for „return Crimea to the motherland“.

${ }^{19}$ Horbulin V. (2015), „The hybrid war as a key tool of Russian geostrategy of revenge“, Mirror of the week in Ukraine, no. 2.

${ }^{20}$ Ruszczenko I. (2015), „The Russia-Ukraine Hybrid War: Sociological Perspective“, Kharkov, Ukraine: Tim Pabasz Grup, p. 18.
} 
toja sąvokos „Rusijos galia“ ir mini „šią šalį“ („та сторона“) ${ }^{21}$. Kaip Olga Wasiuta teisingai pažymėjo, hibridinio karo prieš Ukrainą atveju yra dar viena problema - priešas nèra žinomas ${ }^{22}$. Taip pat derètų pabrèžti, kad konfliktas vis dar egzistuoja, o veiksmai daugiausia yra nukreipti ị Ukrainos piliečius, prieš juos naudojant propagandą ir psichologinį karą. Nauja karo metodika neabejotinai prisidejo prie tokios apibrežzimo sąvokų painiavos.

Rusijos propagandos strategijos tikslas buvo sudaryti nuomonę apie Ukrainą, kaip šali, kuri po 2013 m. revoliucijos nepajègia egzistuoti savarankiškai. Turimomis žiniomis, gerokai prieš krizę Ukrainoje, 2008 m. balandžio mėn., Bukarešte vykusio NATO viršūnių susitikime Vladimiras Putinas tvirtino, kad „Ukraina net nèra valstybé! Kas yra Ukraina? Dalis jos teritorijos yra Rytų Europoje, o kita dalis, didelè dalis, yra mūsų dovanota!" Savo 2014 m. kovo 18 d. kalboje, skirtoje Krymo aneksijai, Putinas pareiške, kad rusai ir ukrainiečiai „yra viena tauta. Kijevas yra Rusijos didmiesčiu tėvas. Kijevo Rusia yra mūsų bendros šaknys ir mes negalime gyventi vieni be kitų“. Nuo tada Putinas daug kartų kartojo panašius teiginius. 2020 m. vasario mėn., duodamas interviu, jis dar kartą pareiškè, kad ukrainiečiai ir rusai „yra viena ir ta pati tauta", ir netiesiogiai leido suprasti, kad Ukrainos nacionalinè tapatybė susiformavo kaip užsienio kišimosi rezultatas. Panašiai tuometis Rusijos ministras pirmininkas Dmitrijus Medvedevas 2016 m. balandžio mẻn. sumišusiam komunistų partijos aparato darbuotojui pasake, kad Ukraina „nebuvo jokia valstybë“ nei prieš $2014 \mathrm{~m}$. krizę, nei po jos ${ }^{23}$. Tokiomis kabomis buvo siekiama parodyti, kad Ukraina yra istoriškai atsitiktinai sukurta šalis, o jos piliečiai turètų paklusti Maskvos politikai ir neprieštarauti jos valiai. Taip, be kita ko, buvo siekiama slopinti jaunuolių patriotinius jausmus, jei šie noretų ginti savo tèvynę per antiteroristinę operaciją (ATO). Be to, studentai yra provakarietiškų socialinių revoliucijų ir pokyčių šalyje varomoji jẻga praktiškai nuo pat Ukrainos nepriklausomybès paskelbimo $1991 \mathrm{~m} \cdot{ }^{24}$ Bendros kultūros ir istorijos akcentas taip pat turejo sutrikdyti jaunuolius ir išugdyti Vakarų (įskaitant Vakarų Ukrainą) kaip Rusijos priešo sampratą. Šios psichologinès propagandos

\footnotetext{
${ }^{21}$ Sereda S., Kholodov P. (2020, July 15) „That country“. Why does Zelensky avoid mentioning Russia when talking about the war in Donbass?, Radio Svoboda, https://www.radiosvoboda.org/a/30728032.html, accessed 11. 10. 2020.

${ }^{22}$ Wasiuta O. (2016), „The genesis of the concept and change of approach to hybrid war in the Western political and military discourse", Przeglad Geopolityczny, 17, pp. 26-40.

${ }^{23}$ Düben B. ( 2020, July 1), „There is no Ukraine“: Fact-Checking the Kremlin’s Version of Ukrainian History", https://blogs.lse.ac.uk/lseih/2020/07/01/there-is-no-ukraine-fact-checking-the-kremlins-versionof-ukrainian-history/, accessed 11. 10. 2020.

${ }^{24}$ Kamionka M. (2019), „Revolutionary patterns of behavior of Ukrainian youth student on the example of the Sumy «Revolution on the grass» in 2004", in: Y. Kuzmenko, M. Kamionka, Problems of European integration and democracy in awareness of Ukrainian and Polish youth, Nizhyn 2019, pp. 80-92.
} 
operacijos naudojamos, siekiant pakeisti ar tam tikra kryptimi paveikti oponentų sąmoningumą. Rusijos tikslas - formuoti tokį oponento suvokimą, kokio tikimasi. Plačiąja prasme psichologinès operacijos apibrěžiamos kaip planuotas komunikacijų naudojimas, siekiant paveikti konkrečios žmonių grupés (ypač jaunuolių) požiūrị ir elgesį. Jas sudaro politiniai, ideologiniai ir kariniai veiksmai, orientuoti ị konkrečios tikslinès grupes elgesị ir požiūrị. Tokios operacijos tikslas - formuoti oponento sąmonę ir konceptualią aplinką taip, kad joje būtų palankiai vertinami agresoriaus tikslai ${ }^{25}$. Hibridinis karas nepakeičia karo pobūdžio. Hibridinio karo, kaip ir bet kokios kitos formos kare, centre išlieka smurtas, o jo tikslas yra tas pats, kaip ir bet kokio kito karo, - išnaudoti grèsmę arba naudoti organizuotą smurtą, siekiant igyti fizinių ar psichologinių pranašumų prieš oponentą ${ }^{26}$.

Apibendrindamas Stephenas Nathansonas apibūdina patriotizmą kaip ypatingą meilę, apimančią asmeninị susitapatinimą, ypatingai rūpinantis šalies gerove, ir pasirengimą aukotis dẻl jos gèrio ${ }^{27}$. Patriotizmas (ypač jaunosios kartos, kuri dažnai yra šauktinių i karo tarnybą amžiaus) yra mažiausiai dviejų hibridinio konflikto komponentų taikinys. Pirmojo - propagandos, kuri apibrežiama kaip „bet kokia komunikacijų forma, palaikanti nacionalinius tikslus, kuriais siekiama paveikti bet kurios grupès nuomonę, emocijas, požiūrị ar elgesí, siekiant tiesiogiai arba netiesiogiai padèti organizatoriui i ${ }^{{ }_{28} 8}$. Anot Philipo Tayloro, „tai yra sąmoningi, metodiniai ir planuoti sprendimai, siekiant taikyti ịtikinèjimo metodiką, skirtą konkretiems tikslams pasiekti, ir taip padèti proceso organizatoriams ${ }^{\text {“29. }}$. Antrasis komponentas - psichologinès operacijos, kurios yra planuotos ir skirtos parinktos informacijos ir rodiklių perteikimui užsienio auditorijai, taip siekiant paveikti jos emocijas, motyvus, objektyvų samprotavimą ir galiausiai užsienio vyriausybių, organizacijų, grupių ir asmenų elgesị. Psichologinių operacijų tikslas - skatinti arba stiprinti iniciatoriaus tikslams palankų užsienio subjektų požiūrị ir elgesį. İdomu tai, kad kai kurie mokslininkai net sieja Rusijos televizijos skleidžiamą propagandą su separatistų vykdomų ukrainiečių užimamų pozicijų apšaudymų dažnumu ${ }^{30}$.

\footnotetext{
${ }^{25}$ Shleifer R. (2011), „Perspectives of Psychological Operations (PSYOP) in Contemporary Conflicts", Essays in Winning Hearts and Minds, Sussex: Sussex Academic Press, p. 145.

${ }^{26}$ Wither J. (2016), „Making Sense of Hybrid Warfare“, Connections: The Quarterly Journal. 15, pp. 73-87. 10.11610/Connections. 15.2.06.

${ }^{27}$ Nathanson S. (1993), Patriotism, Morality, and Peace, Lanham: Rowman \& Littlefield, pp. 34-35.

${ }^{28}$ NATO Military Public Affairs Policy (2011), MC 0457/2, February, https://www.nato.int/ims/docu/milpol-pub-affairs-en.pdf, accessed 12. 10. 2020, p. 32.

${ }^{29}$ Taylor P. M. (1995), Munitions of the Mind. A history of propaganda from the ancient world to the present era, Manchester and New York: Manchester University Press.

${ }^{30}$ Yuskiv B. (2017), „The role of media propaganda in the hybrid war“, Actual problems of internacional relations, 27-43. 10.17721/apmv. 2017.132.0.27-43.
} 


\section{Mokslinio tyrimo metodika}

Patriotizmo lygio ir kitiems duomenims nagrinèti naudoti du metodai. Pirmasis, pritaikytas Ukrainos studentų apklausai (apklausoje dalyvavo 17-24 metų jaunimas), buvo individualių nuodugnių pokalbių (NP) metodas, klasikinio kokybinio metodo pavyzdys. Pokalbiuose dalyvavo 16 studentų iš ịvairių Ukrainos regionų ${ }^{31}$, kurie yra akademiniai centrai, įsikūrę Užhorode (Pietvakarių Ukrainoje), Lvove (Vakarų Ukrainoje), Nižyne (Šiaurès Ukrainoje), Perejeslave (Vidurio Ukrainoje), Sumuose (Šiaurès Rytų Ukrainoje) ir sostinejje - Kijeve. Nuodugniems pokalbiams studentai buvo atrenkami atsitiktinai iš socialiai aktyviausių pasirinkto akademinio centro studentų. Antrasis buvo kiekybinių tyrimų metodas - studentų (dieninio skyriaus) apklausa auditorijose pasirinktuose Ukrainos universitetuose. Anketinès apklausos būdu atliekamo tyrimo imtị sudare 1043 respondentai iš Ukrainos. Buvo taikoma sąmoninga atsitiktiné atranka. Atsitiktinès atrankos etape buvo atliekama daugiapakope atranka. Šiuo tikslu buvo naudojamos iš anksto apibrèžtos grupès. Keturiolika universitetų buvo atrinkta tikslingai, taip siekiant užtikrinti palyginti aukšto lygio imties teritorinę diferenciaciją. Tuo pačiu metu atsitiktinès atrankos etape pirmo laipsnio imties vienetai buvo fakultetai, antro laipsnio - institutai, trečio laipsnio - studijų sritys, ketvirto laipsnio - studentų klasės. Kokybinio tyrimo anketą sudarè 86 klausimai ir metrika, o tyrimas buvo atliekamas nuo antros $2017 \mathrm{~m}$. pusè iki 2018 m. pabaigos Charkove, Nižyne, Chersone, Černivciuose, Kijeve, Dniepre, Hluchive, Poltavoje, Sumuose, Lvove, Odesoje, Perejeslave, Užhorode ir Vinycoje. Verta paminèti, kad tyrimas nebuvo atliekamas Krymo teritorijoje ir Rytu Ukrainoje, kurios nepavaldžios centrinèms valdžios institucijoms.

Straipsnyje siekiama aprašyti studentų požiūrị i patriotizmą hibridinio karo laikotarpiu (derètų pabrèžti, kad karas tebevyksta, propaganda internete skleidžiama kur kas intensyviau). Atliekant statistinę analizę ir rengiant straipsni, buvo siekiama patikrinti šią tyrimo hipotezę:

H1: jaunuoliai laiko save patriotais, nepaisydami išorinių hibridinių veiksmų itakos ir bendros situacijos Ukrainoje.

\section{Rezultatai}

Teiraudamasis studentų apie patriotizmą, autorius nesusitelkẻ vien tik $\mathfrak{i}$ tiesioginị klausimą - ar jie yra patriotai, bet pateikè plačią klausimų grupę, pa-

\footnotetext{
${ }^{31}$ İvairūs tyrejai taiko skirtingus Ukrainos skirstymo ị regionus variantus.
} 
dèsiančią nustatyti visus įmanomus kintamuosius ${ }^{32}$. Straipsnyje autorius naudoja tik dalį didelio duomenų kiekio, surinkto vykdant Lenkijos Nacionalinio mokslo centro finansuojamą projektą (dotacijos Nr. 2016/23/D/HS5/00902).

İdomu tai, kad pirmasis atsakymas jau galètų parodyti apklausoje dalyvaujančio jaunimo požiūrị aptariama tema. Taigi, 2 pav. parodyta, kad daugiau nei $78 \%$ respondentų didžiuojasi, būdami ukrainiečiais. Apie $10 \%$ respondentų buvo priešingos nuomonės; $11 \%$ studentų negalejo atsakyti ị šs klausimą. Šiuo metu vertètų paminèti, kad tyrimo metu atlikta apklausa buvo atliekama rusakalbių gyvenamuose regionuose, tokiuose kaip Odesa ar Chersonas (šalies pietuose), taip pat tuose regionuose, kurie yra $10 \mathrm{~km}$ atstumu nuo Rusijos Federacijos sienos, tokiuose kaip Hluchivas (Sumų srityje, šalies šiaurès rytuose). Atsižvelgiant ị minètąjį užsitęsusị hibridinị karą dèl jaunų ukrainiečių „protų ir sielų", šis rezultatas rodo, kad studentai Ukrainoje didžiuojasi būdami savo šalies piliečiais.

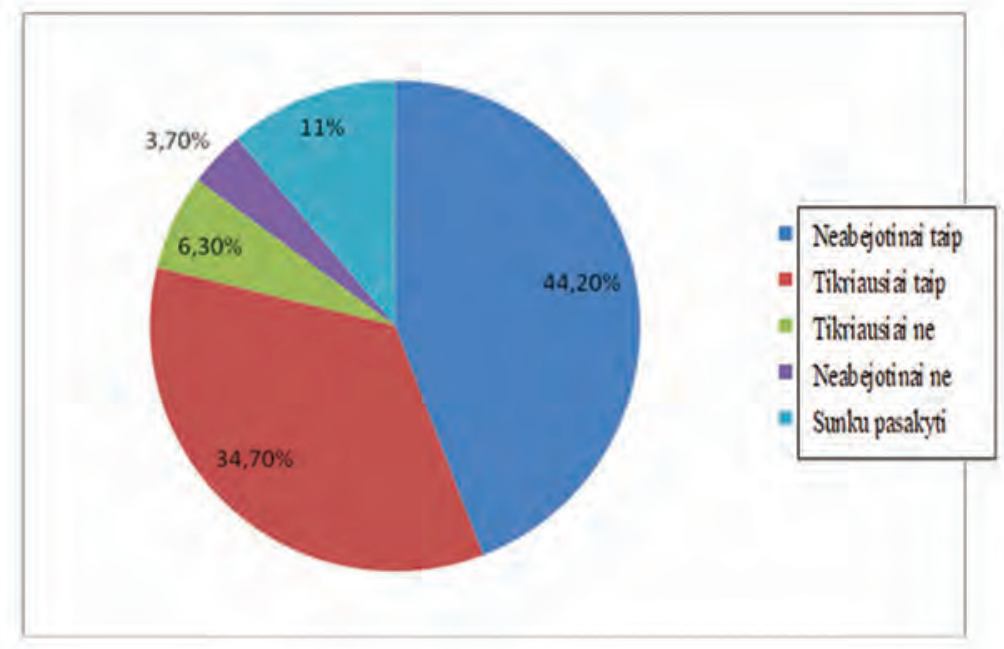

\section{2 pav. Ar didžiuojatès būdamas(-a) ukrainiečiu(-te)?}

Šaltinis: autoriaus tyrimas

Studentų taip pat buvo teiraujamasi, ar jie laiko save patriotais (3 pav.). „Neabejotinai“ ir „tikriausiai taip“ atsake 67,2\% respondentų (21\% studentu atsakymai buvo ryžtingi), palyginti su 15,4 \% jaunuoliu, kurie atsake „tikriausiai ne“, o 6,5 \% atsakè neigiamai. Kaip ir uždavus ankstesnị klausimą, maždaug

\footnotetext{
${ }^{32}$ Atlikdamas kokybinius tyrimus, autorius pateikè klausimus: Ką jums reiškia patriotizmas? Ar manote, kad jaunimas Ukrainoje yra patriotiškas? Kaip vertinate jų patriotizmą? Jei vaizduotumète tikrą patriotą, kaip jị apibūdintumėte? Ar manote, kad patriotizmas visada reikalauja kažkokios aukos?
} 
$11 \%$ žmonių i jị neatsakè. Galime daryti išvadą, kad galbūt $11 \%$ respondentų patriotizmo tema nedomina ir jie neturi apie tai tvirtos nuomonès.

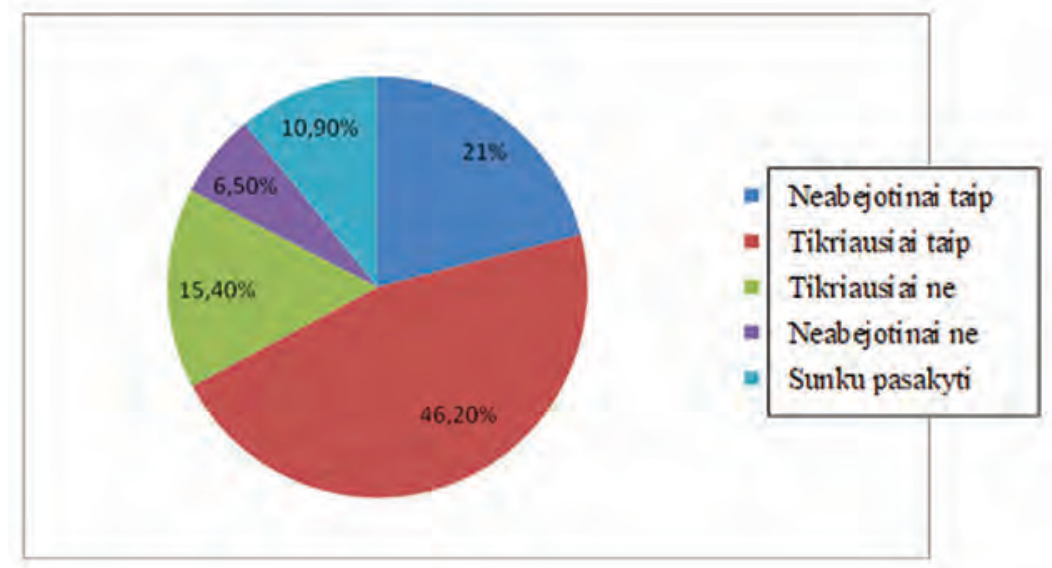

3 pav. Ar laikote save patriotu (-e)?

Šaltinis: autoriaus tyrimas

Atliekant kokybinį tyrimą studentų taip pat buvo klausiama, ką jiems reiškia patriotizmas ir kas, jų manymu, yra patriotas. Šios žinios išplès ankstesnius kiekybinio tyrimo rezultatus. Pokalbių su studentais metu patvirtinti kiekybinio tyrimo rezultatai. Dažnai nurodoma, kad apklausoje dalyvavę studentai jaučia gana stiprius patriotinius jausmus.

Mano manymu, patriotas yra žmogus, kuriam šalies interesai svarbesni už jo paties interesus. Ar esu labai patriotiškas? Tai priklauso nuo to, su kuo lyginsime. Na, ar laikau save patriotizmo pavyzdžiu, tuomet - tikrai ne (1 studentas iš Lvovo).

Patriotas yra asmuo, kuriam patinka jo šalis, žemė, ir tai nepriklauso nuo to, kokią religiją toks žmogus išpažịsta, svarbiausia yra mègti vietą, kurioje gimei. Jaučiuosi esąs patriotas, nes man patinka mano valstybè ir aš čia jaučiuosi gerai (1 studentas iš Užhorodo).

Patriotizmas yra tada, kai žmogui labai patinka jo šalis ir jis daro viską tam, kad ji būtų stipri bei neatsiliktų nuo kitų išsivysčiusių šalių. Galiu save vadinti patriotu (4 studentas iš Nižyno).

Yra ir stebinančios informacijos, pavyzdžiui, nuomonè, kad patriotizmas išgelbėjo Ukrainą (tikriausiai karo Rytuose kontekste). Derètų atkreipti dėmesị, kad jaunuoliai pripažįsta teigiamą patriotizmo poveikị visuomenei. Be to, nors viena iš hibridinio karo dalių yra patriotinių jausmų ir moralinių vertybių slopinimas, didžiojoje šalies teritorijoje ji nebuvo sèkminga. 
Man patriotas yra žmogus, kuris ne tik myli savo šalį, bet ir bando kažką pakeisti savo šalyje, nori pagerinti gyvenimo sąlygas. Jaučiu, kad esu patriotas. Manau, kad jei kalbos apie patriotizmą dabar nebūtų populiarios, abejoju, ar šiandien Ukraina būtų nepriklausoma valstybè (1 studentas iš Sumų).

Apklausoje dalyvavęs studentas iš Kijevo taip pat pastebejo, kad pilietine visuomenè susiformavo Ukrainoje tik po 2013 m. ìvykusios Orumo revoliucijos (Euromaidano). Pilietinè visuomenè ir savanorių judejimas $2014 \mathrm{~m}$. hibridinio karo pradiniame etape kaip tik tapo šalies gynybos stuburu. Tuo pat metu gynybos pagrindą sudarè savanoriai kariai ir savanoriai fronte. Taip pat verta pabrěžti, kad jis rèmési konservatyvia patriotizmo koncepcija - kova už savo šalį.

Žinoma, kad jaučiuosi kaip patriotas. Jei kalbèsime apie pilietinị patriotizmą, jis yra i̇manomas tik šalyje, kurioje pilietinè visuomenè jau yra susiformavusi. Ukraina dar tik pradeda formuotis. Tik Orumo revoliucija pradejo ši pilietinio sąmoningumo formavimosi etapą ir negaliu pasakyti, ką žodis „pilietis“ reiškia man. Pavyzdžiui, mūsų tėų pasaulio samprata yra visiškai kitokia. Nepaisant to, trumpai tariant, patriotizmas yra meilè savo šaliai ir noras už ją kovoti (2 studentas iš Kijevo).

Studentai iš Nižyno (2) ir Perejeslavo (3) savo kalboje minèjo diskusijas, supriešinančias patriotizmą ir nacionalizmą, kurios vyko ne tik šalyje, bet ir trečiosiose šalyse ${ }^{33}$. Jie nori parodyti, kad Ukrainos patriotai nèra nacionalistai, o tai yra savigyna, kurią skatina prieš Ukrainą nukreipta propaganda: teigiama, kad naciai kilo iš patriotų, o tai turètų paveikti rusakalbius gyventojus. Antroje pareiškimo dalyje susitelkiama ị kitą propagandos rezultatą, t. y. Ukrainos nacionalistų sukurtą Didžiąją Ukrainą. Vis dèlto iš studentų pareiškimų aišku, kad, jų manymu, Ukrainos patriotai laiko save demokratiškų Vakarų dalimi.

Taip, apie tai reikia kalbèti, nes patriotizmas nèra nei nacionalizmas, nei nacizmas. Patriotizmo klausimas yra ypač aktualus tokioje šalyje kaip mūsų, kurioje vyksta karas. Yra žinoma, kad patriotizmas nèra tokia radikali politinè jèga. Net Ukrainos patriotai laikosi kai kurių visuotinių Europos vertybių ir orientuojasi $\mathfrak{z}$ vèlesnị susijungimą su Vakarais (2 studentas iš Nižyno).

Taip pat padaugejo nacionalistinių judejjimų ir reikia suprasti, kad patriotai yra ne tik nacionalistai. Vis dèlto po $2014 \mathrm{~m}$. Maidano įvykių galime pastebèti patriotų skaičiaus didejiimo tendencijas (3 studentas iš Perejeslavo).

4 pav. taip pat patvirtina anksčiau tyrimo metu gautą informaciją. 40,2 \% respondentų myli savo tèvynę; panašus jų skaičius (40,5 \%) ją šiek tiek myli. Tik maždaug $12 \%$ (šiek tiek ir neabejotinai) nieko nejaučia Ukrainai. Kita vertus, neapsisprendusiųjų skaičius sumažejjo iki 7,5 \%, t. y. tų studentų, kurie nesijaučia patriotais, tačiau myli savo šalị.

\footnotetext{
${ }^{33}$ Nacionalists staged riots near the building of the Verkhovna Rada (2014, October 14). Retrieved from www.actualcomment.ru/natsionalisty_ustroili_besporyadki_u_zdaniya_verkhovnoy_rady.html, accessed 11. 10. 2020.
} 


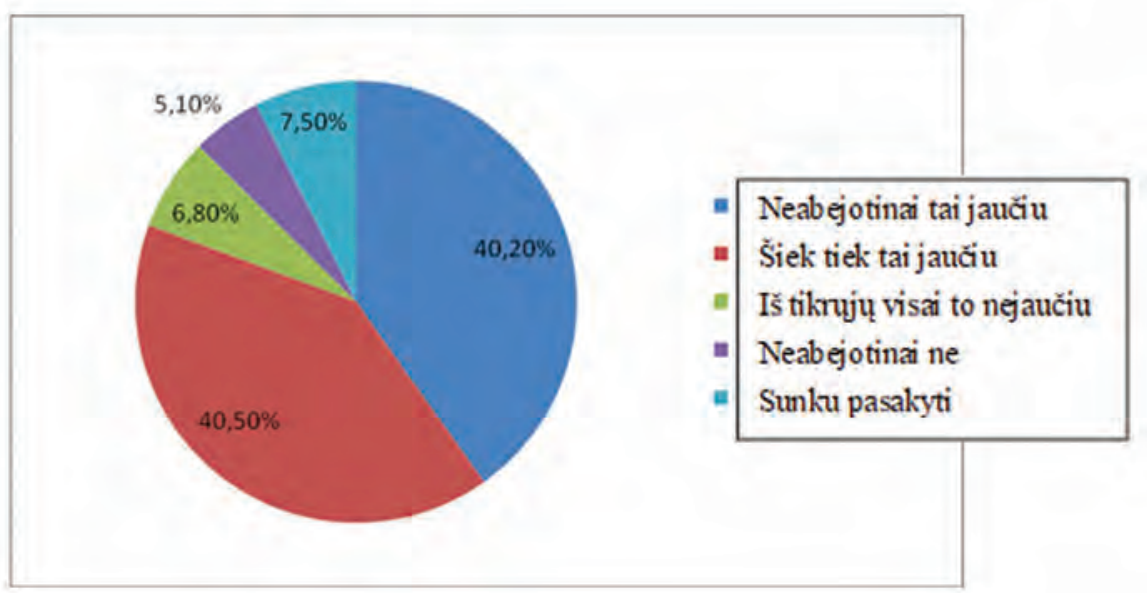

\section{4 pav. Kai kurie žmonės bando apibrèžti patriotizmo sąvoką kaip „meilę gimtinei“. Ar labai stipriai jaučiate meilę Ukrainai?}

Šaltinis: autoriaus tyrimas

Daugiau nei 80 \% apklausoje dalyvavusių studentų myli savo šalį. Dabar būtų logiška aptarti, ką jiems reiškia gimtinè. Dauguma apklausoje dalyvavusio jaunimo ją siejo su vieta, kurioje užaugo ir kuriai jaučia asmeninius jausmus.

Šeimos žemé, kurioje aš užaugau. Tai vieta, ị kurią sugrị̌ęe jaučiuosi visiškai kitaip, jaučiuosi kaip namuose. Žinau, kad čia jaučiuosi patogiausiai (1 studentas iš Lvovo).

Tẻvynė yra vieta, kurioje gimei, vieta, kurioje užaugai, kuri tau suteikẻ gyvenimą, tai vieta, ị kurią norisi sugrižti, nepaisant visų kliūčių, norisi mylèti šią vietą ir norisi ją pakeisti i gera (1 studentas iš Sumų).

Gimtinė yra Tavo žemè. Tai žemé, kurioje gimei, kiekvienas tai suvokia skirtingai, kai kam tai yra šilto pieno skonis, kitam tai yra maistas, bet tai yra kažkas Tavo, kur prabėgo Tavo vaikystė (1 studentas iš Perejeslavo).

Vis dèlto vienas iš apklausoje dalyvavusių studentų nesusiejo gimtinės su gimimo vieta. Jis ją susiejo su vieta, kurioje žmogus jaučiasi gerai. Koks yra modernistinis požiūris ì patriotizmą?

Tẻvynè yra vieta, kurioje jautiesi patogiai. Be to, ji nepriklauso nuo vietos, kurioje gimei (3 studentas iš Perejeslavo).

Kita vertus, studentai iš Nižyno aiškiai ịsitikinę, kad jų tėvynė yra tik Ukraina. Savo pareiškimuose jie pabrèžia, kad tik vieta, iš kurios esi kilęs (kurioje gimei), gali būti laikoma tèvyne.

Man Tẻvynè asocijuojasi su miestu, kuriame gyvenu, bet daugelis žmonių Tẻvyne vadina Ukrainą. Jei esate tikras patriotas, turètumète omenyje Ukrainą (4 studentas iš Nižyno).

Tẻvynè yra Ukraina ir visų ukrainiečių galvose tai yra nacionalinė frazė. Mes iš karto tapatiname Tẻvynę su Ukraina. Šalis, kuri gali būti Tẻvyne ir tiems, kurie iš jos išvyko. 
Žodis „Tẻvynë“ yra kilęs iš žodžio „tèvas“. Tai reiškia, kad tai yra vieta, iš kurios Tavo šeima yra kilusi, Tavo šaknys. Kiekvienam ukrainiečiui Tẻvynè yra Ukraina (6 studentas iš Nižyno).

Studentas iš Kijevo neabejotinai pateikè įdomiausią atsakymą. Jis pabrèžè, kad jam svarbi yra šalies kultūra, o ne religija. Vis dèlto įdomu tai, kad jis pripažino, jog Rytų Ukrainos piliečiai taip pat yra ukrainiečiai, kaip ir jis pats. Tai jam patvirtino konfliktas šalies Rytuose. Tai stebina, tačiau tai galima susieti su tuo, jog po konflikto šalies rytuose Vakarų ir Vidurio regionų gyventojai pastebejjo, kad regionai išliko ištikimi, nepaisydami jiems skirtos propagandos itakos ir atskyrimo jèga, vykstant hibridiniam karui.

Man Tẻvynè yra mano šalis. Šiandien tai yra lojalumas tai sienomis apibrěžtai vietai, kurioje gimiau. Tai lojalumas Ukrainai ir jos kultūrai. Jis yra siejamas su tauta. Kalbèdamas apie lojalumą kultūrai, turẻjau omenyje lojalumą bendrai nacionalinei kultūrai, o ne regioninei kultūrai, nes dabar ribos tarp regioninès kultūros yra labai susiliejusios, ypač po Orumo revoliucijos. Mes jautemès taip pat, kaip ir tie patys Rytuose gyvenantys ukrainiečiai, net jei jie kalba rusiškai. Kai jie žuvo už Ukrainą, net su „rusiškais žodžiais lūpose", tai privertè apmąstyti šį dalyką. Tẻvynẻ bendrame Rytų ir Vakarų civilizacijų kontekste. Šiame kontekste labiau jaučiuosi priklausąs Vakarų Europos civilizacijai (1 studentas iš Kijevo).

1 lentelëje pateikiami studentų atsakymai ị klausimą apie pasitenkinimą gyvenimu Ukrainoje, kurie šiek tiek skiriasi. Tik 24,1 \% studentų yra patenkinti, kad gyvena Ukrainoje, 34,4 \% respondentų iš dalies patenkinti. Su tuo šiek tiek nesutinka 18,4\% respondentų, o 7,6 \% respondentų su tuo griežtai nesutinka. Rezultatai rodo, kad, nors daugiau nei $80 \%$ studentų myli savo šali, tik maždaug $55 \%$ jų nori joje gyventi. Tik nedidelè jaunimo dalis patenkinta savo gyvenimu, o neabejotinai patenkinti juo yra tik $14,9 \%$ respondentų, palyginti su $34,4 \%$ tų, kurie yra iš dalies patenkinti (bendrai jie sudaro 49,3\%). 38,7\% studentų nepatenkinti, o 11,9\% respondentų negalèjo atsakyti ị ši klausimą. Vis dèlto daugiau nei pusé Ukrainos jaunimo nèra patenkinti savo gyvenimu studijų etape. Paprastai šis etapas laikomas geriausiu gyvenime. Tokie duomenys kelia nerimą, nes tai gali turèti neigiamos ịtakos jaunimo moralei. Vis dèlto guodžia tai, jog daugiau nei 70 \% jaunuolių mano, kad jų ateitis bus geresnè. 
1 lentelè. Kiek sutinkate su šiais teiginiais?

\begin{tabular}{|l|l|l|}
\hline \multicolumn{2}{|l|}{} & $\mathrm{N} \%$ \\
\hline \multirow{4}{*}{ Esu laimingas, kad gyvenu Ukrainoje } & Visiškai sutinku & $24,1 \%$ \\
\cline { 2 - 3 } & Šiek tiek sutinku & $34,4 \%$ \\
\cline { 2 - 3 } & Šiek tiek nesutinku & $18,4 \%$ \\
\cline { 2 - 3 } & Visiškai nesutinku & $7,6 \%$ \\
\cline { 2 - 3 } & Sunku pasakyti & $15,5 \%$ \\
\hline \multirow{5}{*}{ Esu patenkintas savo gyvenimu } & Visiškai sutinku & $14,9 \%$ \\
\hline & Šiek tiek sutinku & $34,4 \%$ \\
\hline & Šiek tiek nesutinku & $27,4 \%$ \\
\hline & Visiškai nesutinku & $11,3 \%$ \\
\cline { 2 - 3 } & Sunku pasakyti & $11,9 \%$ \\
\hline \multirow{5}{*}{ lateiti žvelgiu su viltimi } & Visiškai sutinku & $39,9 \%$ \\
\hline & Šiek tiek sutinku & $32,9 \%$ \\
\cline { 2 - 3 } & Šiek tiek nesutinku & $11,1 \%$ \\
\cline { 2 - 3 } & Visiškai nesutinku & $6,4 \%$ \\
\cline { 2 - 3 } & Sunku pasakyti & $9,8 \%$ \\
\hline
\end{tabular}

Šaltinis: autoriaus tyrimas

Beveik $80 \%$ apklausos dalyvių pareiškè pasirengę keliauti į kitas Europos šalis (išskyrus Rusiją), siekdami pagerinti savo gyvenimo sąlygas, o tai savaime svarbu analizuojamų duomenų kontekste. Visiškai kitokios nuotaikos siejamos su siūlymu vykti ị Rusiją, nes bet kokios bendradarbiavimo su ja formos buvo nurodomos kaip nepatriotinio požiūrio pavyzdys. Rezultatai aiškiai rodo, kad jaunuoliai, nors ir yra patriotiški, nenorètų laukti pokyčių, kuriais tiki, ir verčiau tuojau pat išvyktų iš savo tèvynès.

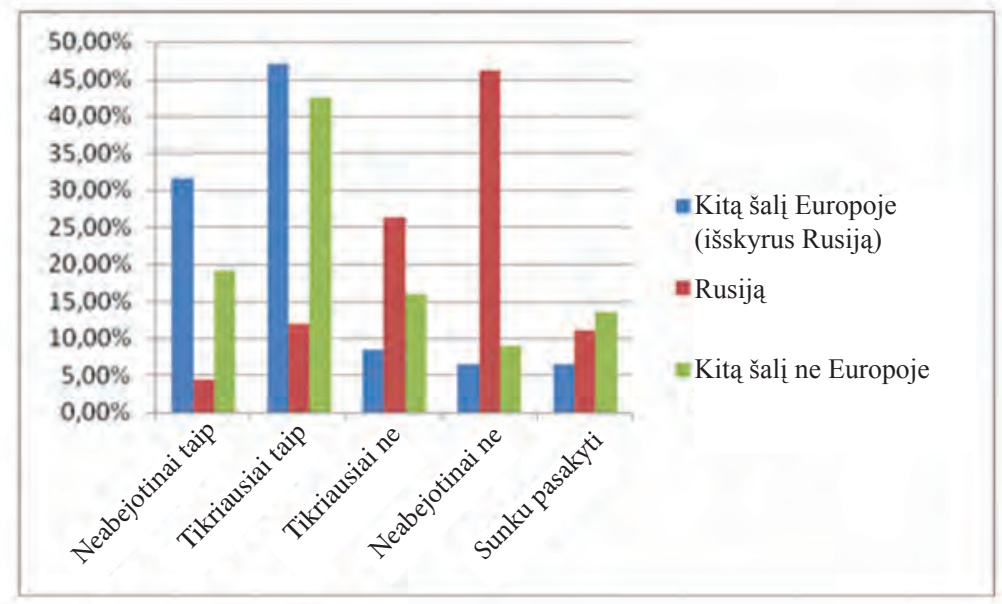

5 pav. Jei pavyktų rasti viliojantị darbą ir pagerinti savo gyvenimo sąlygas, ar persikeltumète $i . . . ?$

Šaltinis: autoriaus tyrimas 
Iš studentų atsakymų matome, kad ne visų požiūris ị bendraamžius, išvykstančius ị užsienị, yra teigiamas. Pasak jų, jaunimo patriotizmo lygis mažèja dèl emigracijos, be to, jaunuoliai negrąžina „skolos“ savo valstybei (pavyzdžiui, už išsilavinimą).

Daugelis žmonių išvyksta ị užsienị ir sako, kad Ukrainoje yra baisu, jie nemano, kad yra kažką skolingi savo Tẻvynei. Tokia jaunuolių grupé nèra patriotai. Studento gyvenime minimalus reikalavimas yra mokèti ukrainiečių kalbą, lankyti visas paskaitas universitete ir nedirbti, pavyzdžiui, padavejju, siekiant užsidirbi pinigų. Toks žmogus turi „kompensuoti“ pinigus, kuriuos valstybè i̇ jị investuoja, tai yra, baigęs mokslus, dirbti Ukrainoje, pavyzdžiui, rengti projektus ir juose dalyvauti (1 studentas iš Sumų).

Patriotizmas? Net negaliu jo vertinti, nes mūsų jaunimas išvyksta iš šalies, dabar yra gerokai mažiau jaunų žmonių, jų skaičius mažèja, jie išvyksta dirbti ị užsienį. Manau, kad patriotizmo lygis gerokai sumažèjo (1 studentas iš Nižyno).

Kai kurie žmonès yra pasirengę išvykti iš Ukrainos, o tai nẻra patriotizmas (2 studentas iš Sumų).

Studentai taip pat tiesiogiai nurodo tebesitęsiantį konfliktą ir visuomenès susiskaldymą Ukrainoje po $2013 \mathrm{~m}$. Paradoksalu, bet, nepaisant to, jie taip pat nurodo, kad Euromaidanas suvienijo visuomenę.

Neseniai susikūrè tokie „subjektai“ kaip DLR, LLR, Novorosija, ir žmonių nuomonès šia tema išsiskiria. Vis dèlto apskritai nesakyčiau, kad susiskaldymas yra gerokai didesnis, priešingai - po Maidano įvykių ir Krymo aneksijos žmonès susivienijo, jie bandè surasti bendrą ryšio tašką (1 studentas iš Perejeslavo).

Vis dèlto studentai ižvelgia Ukrainoje vis dar egzistuojančias silpnąsias vietas, tokias kaip korupcija, kyšininkavimas ir žemo lygio politinis elitas. Galime suprasti, kad studentas iš Vakarų Ukrainos net tarp savo draugų mato žmonių, kurie kariavo dèl pinigų. Kita vertus, studentas iš Vidurio Ukrainos primeta kaltę dèl susidariusios situacijos šali nuo nepriklausomybès paskelbimo valdančiam elitui.

Daugelis niekuo nesidomi. Pavyzdžiui, turiu draugų, kurie išèjo ị karą, manydami, kad tai jų pareiga, kad jie yra šalies patriotai ir nori už ją kovoti, kiti išèjo ị karą, nes dabar armijoje gerai moka ir taip galima užsidirbti papildomų pinigų (1 studentas iš Užhorodo).

Ukrainos atveju reikia kalbẻti apie patriotizmą. Jei mūsų politikai būtų pradèję kalbèti apie patriotizmą dar $1992 \mathrm{~m}$. ir pabrěžę, kad mes esame nepriklausoma valstybė, nesvarbu, kad ir kokia kalba kalbètume, galbūt dabar karo ir nebūtų (4 studentas iš Nižyno).

Naujausi pareiškimai aiškiai rodo, kad hibridinio karo strategija, kuria buvo siekiama palaužti tautos dvasią, buvo nesèkminga, bent jau vertinant jaunąją ukrainiečių kartą.

Man patriotizmas yra kažkas, kas dabar palaiko Ukrainos vienybę, nes be patriotizmo ATO būtų nesèkminga ${ }^{34}$. O galbūt jos net nebūtų, patriotizmas padeda mums kovoti už savo šalị (5 studentas iš Nižyno).

${ }^{34}$ ATO- Anti-Terrorist Operation run by Ukraine in the occupied territories. 
Susiskaldymą lèmė tai, kad žmonès suskirste šalị ị dešiniąją ir kairiąją Ukrainos pusę; anksčiau toks skirstymas buvo ryškesnis. Taip, tai taip pat priklauso nuo situacijos. Jei kabėsime apie situaciją Rytuose, žmonès eina į karą, genami patriotizmo jausmo, jie nori ginti savo vaikus, jie nori, kad žmonès kasdien galètų mègautis gyvenimu, užuot baiminęsi, kad gali žūti. Be to, tai yra atsidavimas žemei, kurioje jie užaugo, ir patriotizmo jausmas (2 studentas iš Sumų).

\section{Išvados}

Rumunų mokslininkas Cătălinas Alinas Costea savo pranešime „Rusijos hibridinis karas Ukrainoje (2014-2018)“ rašè, kad Rusijos Federacijos pradètas hibridinis karas sukèlè didelių problemų Ukrainai, kuri buvo nepasiruošusi tokio pobūdžio situacijai, bet sėkmingai prie jos prisitaike ir kovoja su hibridinėmis grèsmėmis. Konfliktas sustiprino Ukrainos valstybę, jos institucijas, kurios prisitaike prie kovos, vykstant hibridiniam karui ${ }^{35}$. Šiame straipsnyje pristatomi tyrimo rezultatai taip pat rodo, kad hibridinis konfliktas sustiprino ne tik valstybès institutus, bet ir visuomenę, nes daug jaunuolių jaučiasi esą patriotai (apie $67 \%$ ) ir didžiuojasi savo šalimi (daugiau nei $78 \%$ ). Nors dauguma jų myli Ukrainą (daugiau nei $80 \%$ ), kita vertus, nori vykti ị užsienį, jei taip galètų užsitikrinti geresnes gyvenimo sąlygas, tik apie $55 \%$ respondentų yra patenkinti gyvenimu šalyje. Ukrainos studentų dvasia nepalūžo, nepaisant tebevykstančio hibridinio karo ir atakų, nukreiptų ị nacionalinio pasididžiavimo jausmą. Taigi buvo patvirtinta hipotezè, kad, nepaisant intensyvesnių išorinių (taip pat ir vidinių) propagandos atakų, studijuojantis jaunimas Ukrainoje yra patriotiškas. Tyrimo metu jie pabrèžè, kad konfliktas Rytuose padejo jiems suprasti, jog visi žmonès, išgyvenantys šiuos sunkius laikus, yra ukrainiečiai, nesvarbu, kokia kalba kalba ir iš kurio regiono yra kilę. $2013 \mathrm{~m}$. (Euromaidanas) ir 2014 m. (karo šalies Rytuose pradžia) įvykiai paskatino jaunosios kartos „steigiamojo mito“ sukūrimą, kuris tikriausiai daugelị metų išliks jaunuolių patriotinių jausmų pagrindu (jie pasakos istorijas apie šį laikotarpị jaunesniems draugams ar savo vaikams). Guodžia tai, kad nèra esminių skirtumų tarp atsakymų, kuriuos pateikè iš skirtingų šalies dalių kilę studentai. Patys studentai pabrěžia, kad Maidanas ir karas padejo ištrinti jų skirtumus. Nepaisant to, negalima pamiršti, kad jie vis tik suvokia, jog jų gyvenimo sąlygos yra prastesnès nei kitose šalyse gyvenančių jų bendraamžių, tačiau yra pasirengę aukotis dèl būsimų kartų, o ị ateitị žvelgia su viltimi, kad jų situacija

\footnotetext{
${ }^{35}$ Costea C. (2019), SETA Report: Russia's Hybrid War In Ukraine (2014-2018), retrieved from https://setav. org/en/assets/uploads/2019/12/R147En.pdf, accessed 11. 10. 2020.
} 
pagerès (daugiau nei $72 \%$ respondentų). Vis dèlto visuomenė negali pamiršti $7 \%$ užgrobtos Ukrainos teritorijos, nuo tada žuvo daugiau nei 10000 žmonių (įskaitant daugeli aptartoje apklausoje dalyvavusio jaunimo bendraamžių) ${ }^{36}$. Taigi, tai buvo nemaža Ukrainos auka, siekiant pakloti savo tapatybės pamatus būsimoms kartoms.

2020 m. rugsèjis

${ }^{36}$ Talmazan Y. (2019. Feb. 20), „Maidan massacre anniversary: Ukraine remembers bloody day of protests, NBC“,https://www.nbcnews.com/news/world/maidan-massacre-anniversary-ukraine-remembers-bloodyday-protests-n973156, accessed 11. 10. 2020. 